\title{
EVOLUTION OF THE SOUTH-MAZOVIAN CULTURAL LANDSCAPE
}

\author{
JOANNA PLIT \\ Institute of Geography and Spatial Organization \\ Polish Academy of Science \\ Twarda 51/55, 00-818 Warszawa, Poland \\ E-mail: plitjo@twarda.pan.pl
}

\begin{abstract}
Spatial historical analysis is very helpful in research. Historical analyses allow for: the reconstruction of the process underpinning the creation and evolution of cultural landscapes from the Middle Ages up to modern times; the identification of phenomena and processes that are the direct and indirect consequences of historical events; and the reconstruction of cause-and-effect connections between events in a region and the contemporary physiognomy of its cultural landscape.

The details and accuracy of such an analysis are conditioned by quality of materials. Historical research in Poland allows for the acquisition of detailed information for the period of the last 200 years. A study area covering nearly $2500 \mathrm{~km}^{2}$ within the basin of the middle Vistula River was selected for study, this taking in a portion of a wide valley, as well as neighbouring uplands. The area chosen is considered representative of the central part of Poland.
\end{abstract}

Key words: central Poland, changes in cultural landscape, historical analyses

\section{INTRODUCTION}

After years of neglect, the issue of cultural landscapes and their evolution has again become a theme of important bearing for geographers. Today's methodological approaches to the cultural landscape are different from earlier ones, however, and means of definition are different also. Some treat the cultural landscape as an inherited landscape that is the expression of economic activity (Kucera, Kucerova-Kuldova and Chromy 2008); while others see it in terms of anthropogenic impact on naturally-occurring landscapes (Solon 2008). There are also then those who, developing the approaches of Ratzel and Sauer (1925) and Dobrowolska (1948, 1953), perceive the cultural landscape as a new and valuable feature distinguishing itself not only in its appearance (as paysage), but also in its specifics of functioning. These authorities treat the cultural landscape as a synthesis of natural elements and human activities. "A cultural landscape is an historically-formed fragment of the geographic surface resulting from the emergence of the effects of environmental and cultural actions, making a specific structure apparent in regional differences and perceived as an individual physiognomy" (Myga-Piątek 2001). The cultural landscape is an evolutionary form of the areal image, which can be interpreted as the registration of human activity in the geographical environment (Myga-Piątek 2005). Culturál landscapes differ with climatico-phytological zones, but also bear the strong imprint of civilisational and religious spheres.

The cultural landscape is dynamic - not something as it now is, but as it is continually 
becoming - the result of the simultaneous action of natural processes and economic activity. Determining the role and importance of specific factors to the interaction between humans and the environment has become an important topic of landscape analysis that permits reconstruction of the mechanisms of change.

Key differences have been observed between cultural landscapes, as when the process of transformation of some natural landscapes into cultural landscapes lasted many centuries, while others emerged suddenly on untouched ground (Bosch 1961). Where the process had the character of a gradual evolution together with the development of a society, economic activity and changes in production methods, long chains of actions and reactions resulted between human activity and soil-creating processes, in the topoclimate, the evolution of relief (e.g. changes in the strength of processes of erosion and accumulation) and hydrography (melioration: drainage and irrigation), and as regards changes in flora and fauna. In each successive epoch, people have adapted differently to environmental conditions. The development of tools and technology, as well as changes in the organisation of production in the course of the historical process have allowed for ever-fuller exploitation of resources (Dobrowolska 1948). Nature too adapts, and at each stage of the evolutionary process in the relationship between human beings and the environment a new, balanced arrangement has emerged (Kostrowicki 2007). The layering of elements of the cultural landscape originating in different epochs is decisive in determining the wealth and cultural continuity of a region.

When economic and urbanisation processes proceed suddenly this is often destructive for the natural environment, especially when anthropogenic landscapes are created in line with the concept of the subjugation of nature to human economic activity. In such landscapes there is a lack of transitional phases and ecotonic communities, and biodiversity falls acutely; boundaries are sharp, often linear, and in the landscape structure it is geometrically-outlined zones of use that predominate.

The objectives of this paper are:

- to decipher the cultural landscape empirically, treating it as a societal document (Ducan 1990);

- to reconstruct the process by which the cultural landscapes of a Polish province were created and evolved from the Middle Ages through to modern times;

- to identify phenomena and processes that are the direct or indirect consequences of historical events;

- to reconstruct the cause-and-effect connections between events in a region and the contemporary physiognomy of its cultural landscape;

- to determine the effects of landscape change on the way of life of inhabitants and their further economic existence.

\section{METHOD OF ANALYSIS AND CARTOGRAPHIC SOURCE}

The method of investigation applied here was developed in the 1980s. It has in fact been used in a series of analyses (of which this is just the latest) devoted to transformations in the natural environment and cultural landscapes of various Polish regions (e.g. Plit 2003, 2004ab).

The earliest period treated here was analysed on the basis of archival sources and the historical literature. While early events in the settlement and economic exploitation of the region were reconstructed, more detailed studies were available for the last 200 years.

Five map series were gathered, encompassing the entire area or fragments thereof. The scales to all maps were unified photographically, and the cartographic method applied to bring them all under a unified co-ordinate system and identical projection. The basis for further work was taken to be the 1:100 000-scale Military Topographical Map issued in 1994. The oldest maps are charged with significant location errors, re- 
sulting from the lack of mathematical and geodesic foundations. These maps were based upon the few localities for which astronomical measurements of latitude and longitude existed. Initially, these maps were elaborated without the use of precise instruments (e.g. with a lack of precise chronometers causing errors in longitude). In the maps elaborated later much imprecision reflected insufficient density of the triangulation grid, or else the ignorance of the magnitudes of magnetic deviations. Until as late as the middle of the $19^{\text {th }}$ century each side of the river was charted separately.

Maps made use of in the cartographic analysis were:

1. "Carte von West-Gallizien", elaborated on the basis of a sparse and not too precise triangulation grid under the supervision of Colonel of the Austrian army MAYER VON HELDENSFELD, in the years 1797-1803, on the scale 1:28 800. After generalization, the map was published in Vienna in 1808 at 1:172 800. The mathematical foundations of the map neglect the curvature of the Earth, so that errors appear in the meridional orientation of the map sheets.

2. The Map of the Head Quartermaster's Department of the Polish Army. The basis for the grid calculation was constituted by the Bessel ellipsoid. Twisting of many fragments of the map is observed, resulting from a lack of knowledge of magnetic declination. The images of the southern and south-eastern parts of the so-called Congress Kingdom originate from 1832. Table charting was carried out on the scale 1:42 000 , and the map was engraved on the scale of 1:126,000 (situation as of 1837)

3. "Novaia topograficheskaia karta zapadnoi Rosii" ["New topographic map of western Russia", in Russian], published at $1: 84000$ at the turn of the 20 th century. The cartographic projection of the charting was the polyhedral Muffling projection. The basis for the instrumental charting was constituted by the triangulation grid. Field charting was carried out on the scale of $1: 21,000$. On the basis of this map, the Germans published (in the years 1914-15) the "Karte des westlichen Russland" at 1:100 000, which was made use of in the present study.

4. The battlefield map on the scale 1:100 000 , elaborated by the Military Geographical Institute in the 1930s.. The reference basis taken was the polyhedral Muffling projection and the Bessel ellipsoid. This battlefield map is very detailed and precise, with an extensive description. The sheets of interest to our study were developed in 1937.

5. The Military Topographical Map of 1:100 000, published by the Topographical Service of the Polish Army, and elaborated by the State Geodesic-Cartographic Enterprise. The universal transversal Mercator projection and the ellipsoid WGS-84, were assumed. The maps were elaborated in 1994.

A series of maps was elaborated at uniform scales showing the mixture of settlement and road networks in three chosen periods (16th century, 1937 and 1994), as well as the extent of forests at five points in time $(1803,1837,1915,1937$ and 1994). The durability of forest complexes was analysed on a cartogram of frequency of occurrence, created by layering, one onto another, the five maps of the extent of forests in specific periods. For an easier interpretation, the boundaries in specific periods were marked in different colours. Thus one and the same map served in the interpretation of the durability of boundaries.

\section{THE CHOICE OF TERRAIN STUDIED}

A large study area was chosen, as bounded by coordinates $\varphi 51^{\circ} 20^{\prime}-51^{\circ} 50^{\prime}, \gamma 2^{\circ} 15^{\prime}-22^{\circ} 05^{\prime}$, and hence covering nearly $2500 \mathrm{~km}^{2}$ lying within the basin of the middle Vistula River, taking in a portion of a wide valley as well as neighbouring uplands. The various parts of the terrain mentioned are in the physico-geographic regions of: the Kozienice Plain, Radom Plain, middle Vistula Valley, Zelechów Upland, Wieprz Spillway, Lubartów Upland 
and Nałęczów Plateau (Kondracki 1972). The boundaries of the natural regions are indistinct in nature and are applied as a matter of convention. Relief is only indicative of strong erosion: the edge of the Nałęczów loessial plateau is cut by ravines. The majority of the area is taken up by lightly undulating sand-clay periglacial denudation plains. These are forms of glacial or fluvioglacial accumulation of the Central-Polish Glaciation. Through the middle of the study area runs the wide (in places up to even $14 \mathrm{~km}$ ) Vistula Valley, which in the gap across (to the south of the area under analysis) narrows to $2 \mathrm{~km}$. The valley floor is not flat, but is formed by a series of terraces and many kilometres of lowland (filled with peat) on the flanks of the valley, but also by lengths of inactive meandering riverbeds and oxbow lakes. The Pleistocene terraces are gravel and sand (often with dunes); while the Holocene terraces are built mainly of loam and silt deposits. This arrangement (on a smaller scale) is repeated along the lower sections of the Rivers Wieprz and Pilica. Of a different character are the narrow valleys of small rivers, the largest of these being the Okrzejka, Radomka and Zagożdżonka. They flow fast, cutting the edge of the valley and Pleistocene terraces.

In ethnic and cultural terms, the area studied is characterised by uniformity. For 1000 years now, it has been inhabited by a Polish population of Catholic confession. From the 16th century on, Jews also settled here. Before World War II the Jewish portion of the population exceeded $30 \%$ in some localities. A brief 18th-19th-century period of Dutch settlement is noted on the Vistula floodplain (until great floods caused the terrain to be abandoned).

In administrative terms this is an area in which several historical voivodships of Mazovia, Świętokrzyskic and Lublin - came into contact. The path of administrative boundaries and division into parishes has been subject to many changes and shifts down the centuries. The causes were: changes in the Vistula channel; a strengthening or weakening of the influence of the main centres of authority and changes in the conceptualisation of the country's territorial division. Currently, almost the entire area is contained within the boundaries of Poland's Mazowieckie voivodship (province-region).

The choice of this transitional terrain for study was a conscious one: here the influences of particular administrative centres are indistinct. The peripheral location allowed for a more peaceful evolution of cultural landscapes. This meant a better chance of survival during the upheavals of war and other cataclysmic events. The area chosen is considered representative of the central part of Poland.

\section{HABITAT CHARACTERISTICS OF THE STUDY AREA}

This part of Poland is characterised by habitats that are not very fertile, but at the same time very diverse floristically. The Radom and Kozienice Plains represent the range limits for tree species typical of the Świętokrzyskie Primaeval Forest, i.e. beech, fir, spruce, broadleaved lime and English oak, and probably also previously sycamore and yew (Zaręba 1974). Plant communities growing in the southern parts are richer and more diverse in terms of species (the primaeval forests were similar to those of the Małopolska Upland); the further north, the poorer and more monotonous they are (gradually coming to resemble the Mazurian forests).

According to the "Potential natural Vegetation of Poland" (Matuszkiewicz 1995), fertile habitats account for c. $15 \%$ of the area. These are areas of brown soils formed on loess and clays, which are potentially covered with lime-hornbeamforest. Such habitats occur mainly in the SE part of the study area and in smaller swaths in the immediate vicinity of the towns of Ryki, Zwolen and Pulawy, and the village of Brzoza. Fertile habitats take up the greater part of the Holocene fluvial terraces of the Vistula. The alluvial soils had elm and ash forests 
(Ficario-Ulmetum). Today, nearly all the fertile habitats are used agriculturally, the only places remaining uncultivated being the steep sides of loess ravines overgrown by forests and thickets.

The region is dominated by habitats of average fertility and by poor lime-hornbeam woods and oak woods. Swaths of oak habitats (Potentillo albae-Quercetum) are located on gravel and clay-gravel deposits on the scarp terrace of the Vistula Valley between Ryczywól, Kozienice and Pionki. In the SE part of the region it is poor lime-hornbeam forest habitats (Tilio-Carpinetum) that dominate. The greater part is cultivated or used as meadow and pasture, or is sometimes forested.

The sandy Pleistocene terraces and sandy fluvio-glacial accumulation plains have pine forests (Leucobryo-Pinetum) and mixed oak and pine forests habitat (Querco-Pinetum). Large areas of such habitats are found in the $\mathrm{N}$ and NW of the region. Today they are covered by the Kozienice and Stromiec Primaeval Forest complexes, as well as by the Garwolin Forests. The third largest complex of such habitats is found between the Wieprz and the Vistula to the north of Pulawy, and is also forested.

In the valley bottoms and in lower parts without drainage there are wet habitats of floodplain forests and alder woods. These are used as meadows and pastures; on the floodplains - especially between levees there are numerous willow scrub and woodland areas (Salici-Poptuletum) left alone to natural processes.

\section{A BRIEF HISTORY OF SETTLEMENT}

Though the area under study has been inhabited since at least the Neolithic era, as late as 1000 years ago the entire terrain was covered with primaeval forest. The region was again colonised by the Lesser Polanie tribes coming from the south, and by the Mazovians from the north along the Vistula, Pilica and Radomka Valleys. By the 11 th century there were already forts in Ra- dom ${ }^{1}$, Swierże and Sieciechów, by the 12th century market settlements at Magnuszew, Ryczywół, Gniewoszów, Kozienice, Lesiów and Tczów, and villages at Policzna, Strychowice, Sycyna and Kochów, as well as a first fortress at Stężyca. Main routes ran along both sides of the Vistula Valley, and river fords were present at Swierże-Kochów and Sieciechów-Stężyca (Wąsowiczówna 1957). A serious limitation to settlement activity was urged by constant looting raids staged by the Yotwingians (Sudowians), Lithuanians and Tartars along the large river valleys. But as the Polish state strengthened from the 13 th century, a marked increase in population density and economic development followed. The Kings supported the settlement of new people entering the terrain of the Radom Primaeval Forest ${ }^{2}$. Kazimierz the Just gave part of this wilderness over for the building of a friary for the Sieciechów Benedictines (monks on large-scale cleared forest, settled peasants and cultivated fertile terrain). The Benedictine friary brought about improved agriculture and education in the region. It propagated fruit cultivation, horticulture and viticulture. Kazimierz the Great fortified Radom and Sieciechów, and founded Brzoza and Kozłów. In the 14th century a wooden bridge for a road over the Vistula was built at Stężyca (Kurzyp 1989).

The region began to flourish in the Renaissance era as the Vistula became the main transport artery. In the 15-18th centuries trade was mainly in grain, wood, ash, potash and pitch, salt, fish, skins and fabrics (Plit 2004a,b). The most important Vistula rafting port was the town of Stężyca between Sandomierz and Torun; an important function in cattle trading was filled by Ryczywól (town

\footnotetext{
${ }^{1}$ Historical Radom lies to the SE of the study area; while today the suburbs of Radom extend beyond its boundaries.

The Radom Primaeval Forest (Puszcza Radomska) grew over an area in the north from the Święty Krzyż Mountains down to the Rivers Vistula and Pilica. This area was royal property and the favourite hunting-ground of Wladystaw Jagiello. Two large parts of it survive today as the Kozienice and Stromiec Primaeval Forests.
} 
charter from 1409). At the time Zwoleń and Sieciechów were also chartered towns. Near the end of the 16th century settlements were concentrated on upper alluvial terraces of the Vistula and Wieprz, as well as in the edge zone of the valley. Also settled were areas to the $\mathrm{S}$ and $\mathrm{E}$ of Zwolen and the Nałęczów Plateau. In the area analysed there were 215 villages and seven cities. Villages belonging to aristocrats (144) and to the clergy (19) were situated in fertile habitats, while free royal villages (53) were located around the Kozienice and Stężyca Primaeval Forests, as well as in strategically important places (riv- er fords or hills capable of being fortified). the area had four royal towns (Kozienice, Zwoleń, Kazimierz and Stężyca), the aristocracy-owned towns of Magnuszew and Maciejowice, as well as Laskarzew, which belonged to the clergy. Among the chartered towns the largest was Stężyca (Fig. 1).

The next 100 years brought further economic development and an increase in population. Wilderness was cleared, the land won was exploited, new villages and towns sprang up, and intensive trade developed. But the long period from 1650 to 1837 brought war-related destruction. The region

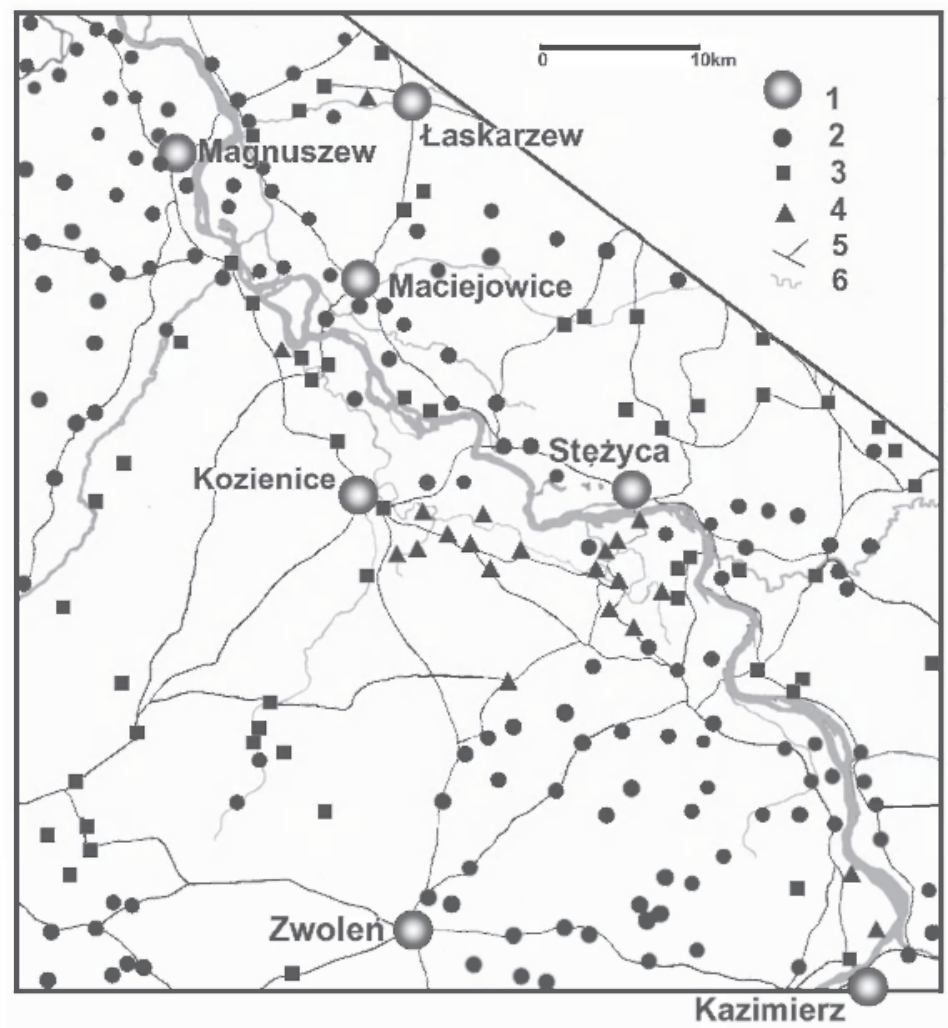

Figure 1 . The settlement pattern in the second half of the $16^{\text {th }}$ century

(Note: Kazimierz Dolny, town on the Vistula river, is located just beyond the investigated area, however, because it has performed key economic functions throughout centuries in the region, it has been included in the Figures)

1 - town; 2 - noble's village; 3 - royal village; 4 - ecclesiastical village; 5 - road; 6 - river (river bed based on 1837 interpretation from Map of the Head Quartermaster's Department of the Polish Army) 
suffered especially during the wars with the Swedes. Armies swept along the Vistula many times, burning, looting and murdering. They burned Magnuszew, Stężyca and Gołąb. A majority of localities suffered, their populations decimated. The upheavals of war brought similar effects at the turn of the 18 th and 19 th centuries ${ }^{3}$. Wars were accompanied by natural disasters (hunger and epidemics), but they at the same time resulted in the faster spread of new ways of cultivating crops and new food crops (e.g. the potato).

The entire 19th century was a period of demographic boom (except for the mid-century potato crop failures and famines) and intensified pressure on the environment. The process of settlement and land development continued in the Vistula Valley, where the most fertile habitats are found. Numerous villages were also located on flood terraces (these were Polish as well as Dutch settlements). The Vistula often changed its channel; dangerous floods increased during the 'Little Ice-Age' (Plit 2004b) ${ }^{4}$. Floods destroyed villages and towns, with some being completely abandoned and others built again elsewhere (e.g. the inhabitants of a few abandoned localities built Nowa Wieś - New Village - at a higher elevation; the village of Świerże had to be relocated three times; the town of Ryczywól was moved $1.5 \mathrm{~km}$ farther from the Vistula channel; and Stężyca and Wargocin were destroyed several times as the Pleistocene terrace was washed away, causing the failure of the localities) (Kurzyp 1989; Plit 2004 a,b).

A second direction to settlement was into wilderness areas, above all where habitats of poor lime-hornbeam woods, oak woods and mixed oak and pine forests were brought un-

\footnotetext{
${ }^{3}$ The Austrian, Russian, French and Polish armies rolled back and forth. It was near Maciejowice that one of the main battles of the Kościuszko Insurrection of 1794 took place.

${ }^{4}$ In 1678 the capture of a lower section of the River Wieprez by the Vistula took place. Catastrophic (especially obstructive) floods ensued, causing wide destruction in the valley, especially in $1600,1678,1713 / 14$, $1736 / 37,1749,1774,1783,1813,1838 / 39,1840,1844 / 45$, $1850,1852,1854 / 55,1867$ and 1871 , as well as in 1934 and 2001.
}

der cultivation. Numerous small settlements and villages arose in clearings. Settlement units already existing around mill buildings and sawmills were built up further. Expansion took in the southern part of the Kozienice and Stromiec Primaeval Forests and the middle Radomka Valley (Fig. 2). The network of towns became denser; in the region the functions of chartered towns were served by Gniewoszów, Kazimierz, Kozienice, Łaskarzew, Maciejowice, Magnuszew, Stężyca and Zwoleń, but actual chartered towns were few in number, and they were weak economically. In many localities, attractive palatial objects with parks were built (as at Pulawy, Kozienice, Dęblin and Podzamcze).

In the years 1837-45, at the fork of the Rivers Wieprz and Vistula in Dęblin, Tsarist armies built a great brick fortress. Part of these fortifications were also bastions built on the left bank of the Vistula. The fortress became the icon of the occupiers in the landscape, a dominating feature not at all suited to its surroundings.

By 1837 , the area analysed had 268 villages and hamlets, as well as eight towns; up to 65 of these were new settlement units (completely new or relegated to other places); 12 destroyed localities had been abandoned. The settlement network had a strongly concentrated character, the main axis of which (as in previous centuries) was the Vistula Valley. The transport network had only become slightly more dense, with but a few sections of road built or modernised. In the second half of the 19th century great changes occurred in the settlement system of the region:

- After construction of levees against flooding ${ }^{5}$, the low-lying fertile terraces along the Vistula were resettled.

\footnotetext{
${ }^{5}$ In the years $1846-56$ on the lower-lying left side of the Vistula, $6.4 \mathrm{~m}$-high flood levees were built from Góra Puławska to Świerże $(26.7 \mathrm{~km})$. Following those measures, erosion increased on the right bank, making it necessary to construct levees there too, but construction was slow and suffered long interruptions. Full enclosure was only completed after WW II.
} 


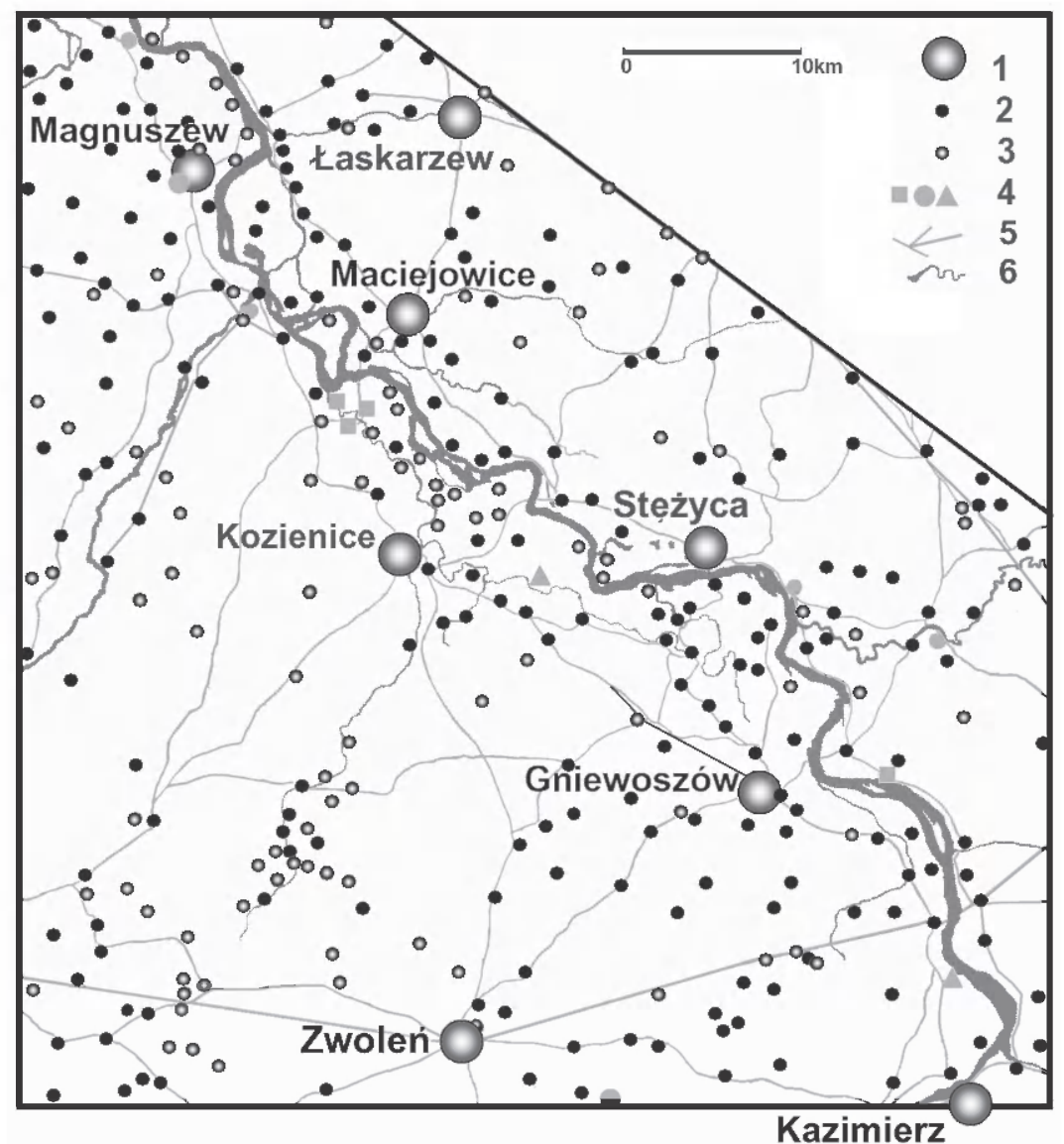

Figure 2. The settlement pattern in 1837 (1 - town; 2 - village; 3 - new village, 4 - non-extant village, 5 - roads; 6 - river) (after the Map of the Head Quartermaster's Department of the Polish Army)

- After the stifling of the January Rising of 1864 by the Russian occupier, Tsarist decree enfranchised the peasants, and forms of forced tenure and labour and peasant serfdom were suspended. This gave impetus to the creation of new localities (often with extensive construction).

- With the measures of political repression after 1870 several small towns lost their charters. This political act approved their de facto status legally, since the inhabitants lived mainly from farming.

In the 20th century, the First World War left its mark on the landscape in the form of huge cemeteries after the battles of Dęblin fortress but caused only insignificant dam- age to settlements in the region. By contrast, the Second World War decimated the population, with Nazi forces murdering almost all Jewish inhabitants. There was partisan activity in the large forests, and many villages were burnt down in the Occupant's campaign of repression. Frontline military action caused great destruction at Maciejowice, Kozienice (1939) and Laskarzew, as well as around the bridgehead at Magnuszew (1944). On the other hand the powerful fortress at Dęblin was bypassed by the fronts, and never taken.

In the second half of the 20th century, industry developed in the region with the location of several industrial plants: in Puławy a large chemical plant (mainly nitrogen ferti- 


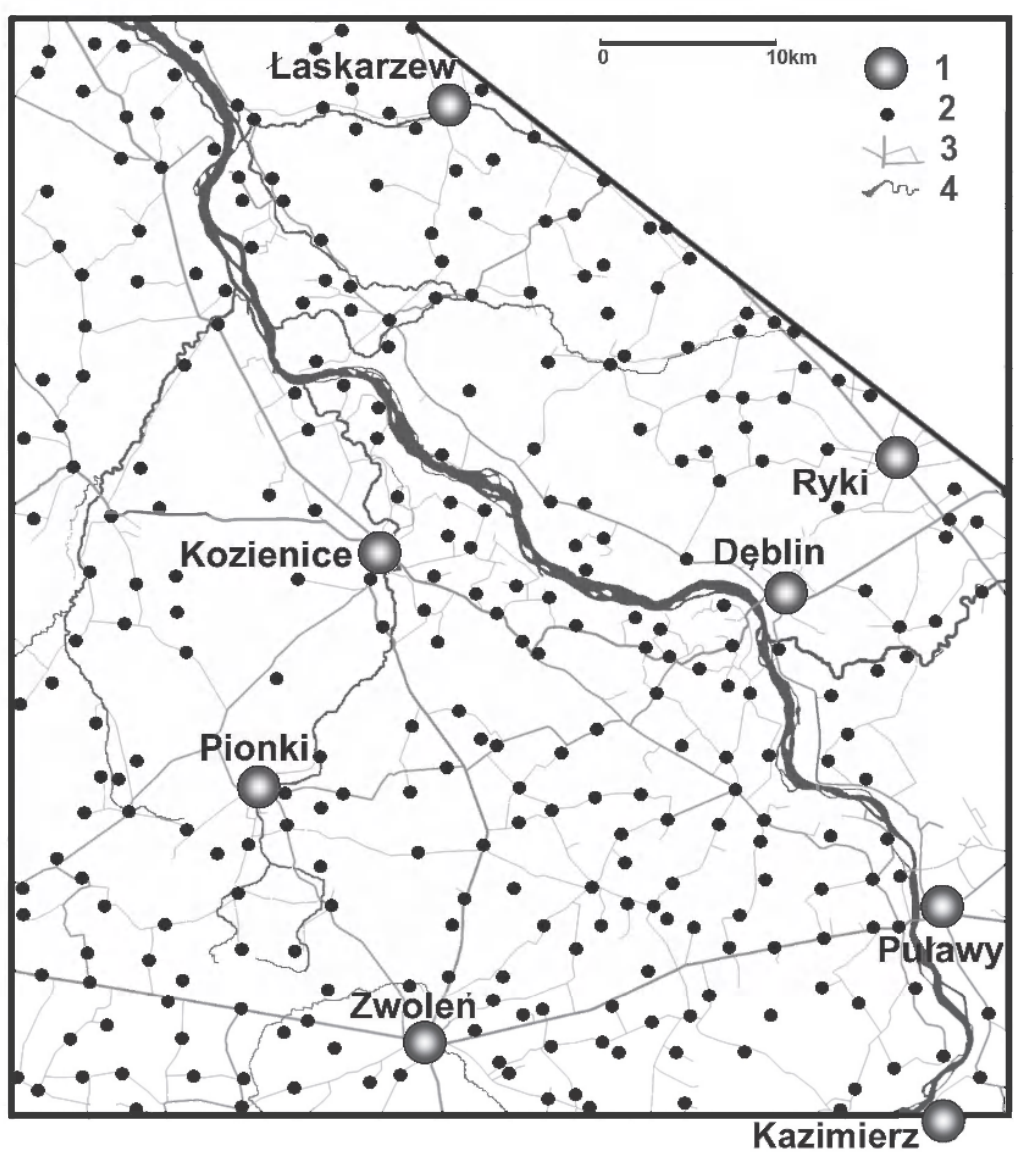

Figure 3. The settlement pattern in 1994 (1-town; 2 - village; 3 - roads of different categories; 4 - river) (after the IGiPZ-PAN Numerical Map of Poland)

lisers), in Pionki chemical and textile manufacturers, in Kozienice a power plant, and in Ryki food processing. These investments had a city-building role: new masonry housing complexes were built in the chessboard-style arrangements of 2- and 3-floor apartment blocks then typical of socialist-bloc cities. The Garbatka and Jedlnia vacation towns were built on the concept of the 'city-park' (Fig. 3). The growing cities and towns absorbed surrounding villages.

The effect of the communist era on the rural landscape in the region was also intense. Multi-storey masonry buildings with flat roofs - schools, administrative buildings and homes in the form of simple six-sid- ed blocks - slowly overwhelmed the local wooden architecture. As in all of Poland, roofing of 'eternite' (asbestos cement) was introduced. Another important landscape element became masts and networks of suspended electric power and telephone lines.

Towards the end of the 20th century the spatial arrangement of the settlement network became more even; there were 267 villages, with the amount of extensive building (scattered-type villages) significant. Many former towns failed and new ones sprang up, e.g. Puławy (1909), Dęblin (1954), Pionki (1954) and Ryki (1957), but Kazimierz (1927), Łaskarzew (1969) and Zwoleń (1925) were again chartered formally. 


\section{CHANGES IN THE EXTENT OF FORESTS AND MEANS OF FOREST USE}

In the Middle Ages the enormous Radom Primaeval Forest (on the left-bank side of the River Vistula) was royal property. The forest was divided administratively into the Stromiec Forest to the north the and Kozienice Forest to the south. In the 13th century part of the Kozienice Forest in the NE was given over to the Benedictine order in Sieciechów for their Abbey. On the right-bank side of the Vistula side there grew the Osieck Forest ( $\mathrm{N}$ of Promnik) and the Stężyca Forest, which for the greater part were the property of aristocrats.

In the 15th and 16th centuries the blocks of forest belonging to the aristocracy or clergy were exploited intensively. The Sieciechów Benedictines cleared and turned into fields the oak-beech woods of the Vistula and Zagożdżonka Valleys. Aristocrats and peasants cleared the Sezżyca wilderness, dividing it into small forest parcels. Settlement actions in wilderness areas were also engaged in by the King. Something approaching preservation was confined to the Kozienice Forest, because royalty had chosen it for their hunting ground.

Ever since Christianity had banned from Slav culture the tradition of the sacred grove, forests had been treated as a utility, and there was no planting of trees on the occasion of great events, as had been the case with the Germanic tribes. The forest was exploited in all possible ways. Old trees as well as various specimens of the most valuable species were cut. The wood of conifers was mostly used in building and for fuel and hardwoods in crafts and as fuel for smithing, while bark served in tanning. This intensive, diversified exploitation lasted many centuries, and resulted in an impoverishment of habitats. Fires and burning in the course of clearing damaged soils, while removal of litter decreased their fertility. Intensive herding caused changes in the undergrowth, eliminated seedlings, damaged saplings, and at the same time encouraged the expansion of other species (e.g. juni- per). Beech and larches were eliminated almost entirely. The numbers of firs, oaks and hornbeams were limited ${ }^{6}$, and a formerly dense forest complex became ragged and fragmented.

In the parts of the forest belonging to the royal estates, great damage was caused by the owners of neighbouring land, but also by tenants (Zielony 1997) ${ }^{7}$. As an inspection of forests from 1765 shows, bee husbandry in the forest lost its former importance, and over-hunting and poaching caused significant reductions in wild game numbers. In 1793, K. A. Mehling carried out one of the first forest management plans in Poland for the Kozienice Forest, determining the permissible clearcut limits, and setting out instructions for the care and regeneration of forests. This inspection of the forest allowed for the establishment of the species composition of stands, and further registered the fact that half of the forests were completely devoid of trees, while $1 / 4$ were areas of reduced standing timber and scrubby terrain, and only $1 / 4$ were rich, mature ecosystems.

Because of herding and the storage of dead wood remnants, natural regrowth and saplings were practically absent from the Forest (Zaręba 1963). The extent of forest in the early 19 th century as represented

\footnotetext{
${ }^{6}$ Some documents from the $16^{\text {th }}$ and $17^{\text {th }}$ centuries have survived, concerning timber rafting in the river haven in Stężyca, and hence providing evidence for the felling of large volumes of beech and larch timber from the Forest of Radom.

${ }^{7}$ From the beginning of the 17 th century the forest complex was administered by the Kozienice district. In 1706 the forest was transformed into the 'Kozienice Estate', and revenues from its exploitation and agriculture within its boundaries were used for the upkeep of the royal court in Warsaw. Nevertheless, not even such a change of management form was able to stem the illegal devastation of the wilderness that had been taking place.

${ }^{8}$ The forest regeneration proceeded slowly. On wasteland the forest regenerated either spontaneously through natural succession, or else was made subject to a process whereby, after two or three years of cultivation, cones from which new trees sprouted were planted on the clearings.
} 
in Fig. $4^{9}$ is enlarged - since forest was also taken to include cut-down areas, scrub, as well as smaller open areas within the forest ${ }^{10}$. Nearer the truth is the extent of forest as reconstructed from the Quartermaster map (Fig. 5): the forest then covers nearly $50 \%$ of the analysed area.

In the 1830 s the rights to herd in state forests, rake forest litter and gather dead wood for fuel were abolished, and artificial reforestation was introduced. Further restrictions on the use of forest were introduced within the framework of peasant enfranchisement. After 1885, the region witnessed the onset of management in 'state forests'. Forest complexes were divided into sections, bare areas forested and damaged trees removed. There was broad-scale clearcutting (with a few years' grain cultivation on clearings thereafter), as well as artificial planting of pines. The process of limiting the extent of forest and dividing up complexes was still going on. The southern and eastern parts of the Kozienice Forest, as well as significant parts of the Stromiec Forest, were reforested. Forests in the drainage basin of the River Radomka were cut down. On the right-bank side of the Vistula the forest complexes between Łaskarzew and Stężyca were divided and delimited. New forests were planted between Puławy, Dęblin and Ryki, partially stabilising the moving sands there (Fig. 6). During the First World War, wood was exploited intensively. For ease of transport, a network of narrow-gauge railways and two large sawmills, at Pionki and Garbatka, were built.

Between the World Wars the process of forest management in the region was concluded. All complexes were divided up by means of a network of aisles. Clearcutting was still practised, but regeneration progressed in the form of plantation. Single-species pine plantations of uniform age were created (Zaręba 1974). The smallest

\footnotetext{
${ }^{9}$ For ease of comparison, all maps depicting the extent of forest show the contemporary hydrography.

${ }^{10}$ Other cartographic productions from the same period, e.g. Czaykowski, 1786 and Perthees, 1791, show different extents of forest, but always less than Mayer's.
}

total surface area of forest in the region was registered in 1937 (Fig. 7). In the years 1915-37 some small forest blocks within fields were cut down and the boundaries of larger complexes evened out, but at the same time some open areas within forests were replanted. The greatest losses occurred in the Stromiec Forest, as well as in the area between Laskarzew, Stężyca and Dęblin. Some forests between Zwoleń, Łagów and Sieciechów were eliminated nearly completely. World War II caused great destruction in forests: total forest removal, fires, damage to existing growth during battles, etc., all took place

Marked growth in the forest area occurred immediately after the War, and this trend continues even today, with mid-forest meadows being planted and wasteland reforested (Fig. 8). Today, forests grow on a somewhat greater area than at the turn of the 19th and 20th centuries. Only between Jedlnia and Pionki can we observe some loss of forest and reductions in its range. The forest-field boundary is complicated and lengthy. In the 20th century the main factor accounting for degradation was forest cultivation - the homogenisation of the species and age composition of growth. These forestry procedures caused a decline in the biodiversity of ecosystems, a lowering of biological resistance, neglect of the use of habitats' natural capacities, and even their degradation. A second factor damaging to forests has been air pollution: local emitters are the nitrogen fertiliser works (Zakłady Nawozów Azotowych) in Pulawy, the chemical works in Pionki and the power plant at Kozienice. From 1983, when Kozienice Landscape Park was created, most forests in this region are under [environmental] protection. The manner of cultivation has also changed: the natural composition of the forest is being restored through the focused planting of fir, beech, oak and lime. The process of stand transformation during the $20^{\text {th }}$ century is capable of being documented by reference to the tree stand maps elaborated periodically by the forest service. 


\section{CHARACTERISTICS OF THE REGION'S CULTURE LANDSCAPE.}

\section{CHANGEABILITY AND PERMANENCE}

Changes down the centuries in the region led to the emergence of half-open landscapes of forest, field and meadow. The main occupations of the populace were (and remain) forestry and agriculture. Three-field farming was introduced by the Sieciechów Benedictines in the 13th century. in turn, four-field systems dominated in the 19 th century, together with potato cultivation, but crop rotation only reopened in the 20 th century. The types of crop changed fluctuatingly, in a process above all connected with long-term climatic change. In warm periods of the Middle Ages viticulture and orchardry played a great part, and wheat was cultivated. During the 'Little Ice-Age' rye, oats, peas and (from the 19th century), root crops dominated. As the climate warmed, there was renewed importance of orchards, plantations of bush fruits, as well as vegetables, while grains and roots continued to be cultivated. Up to the mid-20th century there was a marked upward trend for the area under cultivation, and consequent limitation of the area under forest.

For many centuries it was the exploitation of forest resources plus agriculture that served as the economic base for the region. The remaining wilderness areas were exploited universally, if in diverse ways. However, from the 20 th century on, the approach to forests and their exploitation changed as they began to serve other functions. Table 1 illustrates the magnitude of these changes.

The breakup of forest complexes (see map) was based on changes of a fundamental nature illustrated in Fig. 9. A change of trend occurred in the second half of the 20th century, with the process of the enlargement and consolidation of forest areas continuing up to the present day. Currently the region's forests are in better condition than 300 years ago, as can be observed in the emerging regeneration of habitats, and the enrichment of the species composition.

Fig. 10 offers a chronology for forest complexes in the 19th and 20th centuries. Analysis of the map draws attention to the

Table 1. Different contemporary and past means of utilizing the forests in central Poland, between the 13 th and 20 th centuries (density of hachure corresponding with process intensity)

\begin{tabular}{|c|c|c|c|c|c|c|c|c|}
\hline \multirow[t]{2}{*}{ Kind of activity } & \multicolumn{8}{|c|}{ Aim of activity } \\
\hline & $\begin{array}{l}\text { Fresorina- } \\
\text { tion of } \\
\text { natire. }\end{array}$ & Rest & $\begin{array}{l}\text { Gatherine } \\
\text { of food of foddes }\end{array}$ & $\mid \begin{array}{c}\text { Collection } \\
\text { of } \\
\text { building } \\
\text { ivood }\end{array}$ & $\begin{array}{c}\text { Gathering } \\
\text { of } \\
\text { fuekrood }\end{array}$ & 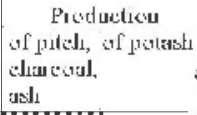 & $\begin{array}{l}\text { Tond } \\
\text { for } \\
\text { agricultur }\end{array}$ & $\begin{array}{l}\text { Fertilizing } \\
\text { ot ficlds }\end{array}$ \\
\hline \multicolumn{9}{|l|}{ Culting trecs } \\
\hline \multicolumn{9}{|l|}{ Pulling stumps } \\
\hline \multicolumn{9}{|l|}{ Cinublong up snags } \\
\hline \multicolumn{9}{|l|}{ Burning is leaming, forest } \\
\hline \multicolumn{9}{|l|}{ Rnking litter } \\
\hline \multicolumn{9}{|l|}{ Erathering bmislnwsod } \\
\hline \multicolumn{9}{|l|}{ Stripyinger loinl: } \\
\hline \multicolumn{9}{|l|}{ Trungin: } \\
\hline \multicolumn{9}{|l|}{ Kerpine hers } \\
\hline \multicolumn{9}{|l|}{ Hunting and poaching } \\
\hline \multicolumn{9}{|l|}{ 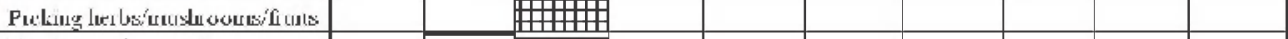 } \\
\hline \multicolumn{9}{|l|}{ Tomrism and rerereation } \\
\hline Limiting access, renaturalising & = & & & & & & & \\
\hline
\end{tabular}

A. means of utilizing forests between the 13 and 18 th centuries

B. means of utilizing forests in the 20 th century 


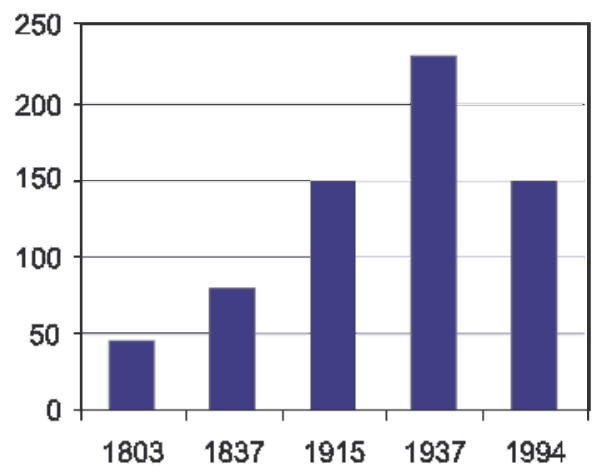

l'igure 9. Jiragmentation of the lorest area in 170 and 20 th centurics

fact that nearly all forests on the Vistula's clay alluvial terraces have disappeared. Away from the zone between the levees, the forests were changed into farmland. Permanent forest exploitation is maintained on the Pleistocene sand-gravel terraces of the Vistula, and in the edge-zone of its valley. The Garwolin Forest, Kozienice Primaeval Forest and the SE part of the Stromiec Forest were all long exploited as forests.

It is worth noting that the boundaries of many forest complexes are permanent, especially those fixed orographically and lithologically. Such boundaries occur along the Pleistocene terrace edges of the Rivers Vistula and Wieprz. Some permanent boundaries have reflected from long-established ownership structures, e.g. in the area of Kozienice and Lagów, and the village of Jedlnia. On the other hand, smaller rural (peasant-managed) forest complexes between Ryki and Maciejowice have been very unstable.

In the second half of the $20^{\text {th }}$ century, the edge of the Lublin Upland, almost completely without forest and [long] exploited agriculturally, overgrew by means of natural succession into undergrowth and then forest. The very complicated boundaries of forest complexes reflect the structure of the terrain (forest growing along the sides and floors of loess ravines, while the flat tops above are still taken for cultivation) $)^{11}$.

\footnotetext{
${ }^{11}$ Estimation of the forested area in the periods analysed was consciously avoided, because:
}

From the 16 th to the 21 st centuries, the area analysed witnessed a near-tenfold increase in population ${ }^{12}$. As new areas were settled, the settlement network became denser. Most 16th-century localities retained the architectural layout of earlier villages and towns. Cluster-type villages dominated, with a distinct (often rectangular) marketplace, on which stood a church, inn, sometimes a town-hall, granary or warehouse. This arrangement is to be found in all former towns (in Stężyca only the northern facade facing the market survives), but also in villages, e.g. in Bobrowniki, Brzeźce, Wysokie Kolo, Bronowicze, Brzóza, Świerże, Ryczywól and Sieciechów. Some villages have elongate forms corresponding to the course of drainage channels, oxbows, or terrace boundaries (e.g. Gołąb, Słowiki, Brzeźnica, Jedlnia and Pawlowice). In the 17-19th centuries the

on old maps, still drawn up without precise triangulation, the boundaries of the forest complexes are traced in an approximate manner, quite roughly, with delimitations of the later periods being increasingly accurate; for the individual series of maps different charting instructions were elaborated, the differences referring to the definitions of the distinctions on the map and the assumed generalisation; e.g. in one case it was assumed that woods of area not smaller than $0.25 \mathrm{sq} . \mathrm{km}$ are shown, while in another one the limit was $0.4 \mathrm{sq} . \mathrm{km}$, and on the two-verst map a wood would be shown where a cluster of trees and bushes were sufficient for a rider on horseback to hide in; treatment of the floodplain forests and willow thickets differed significantly.

12 Estimated data calculated on the basis of the number of parishes in the 16th century, as given in the 'Historical Atlas of Poland' and contemporary statistical yearbooks. 


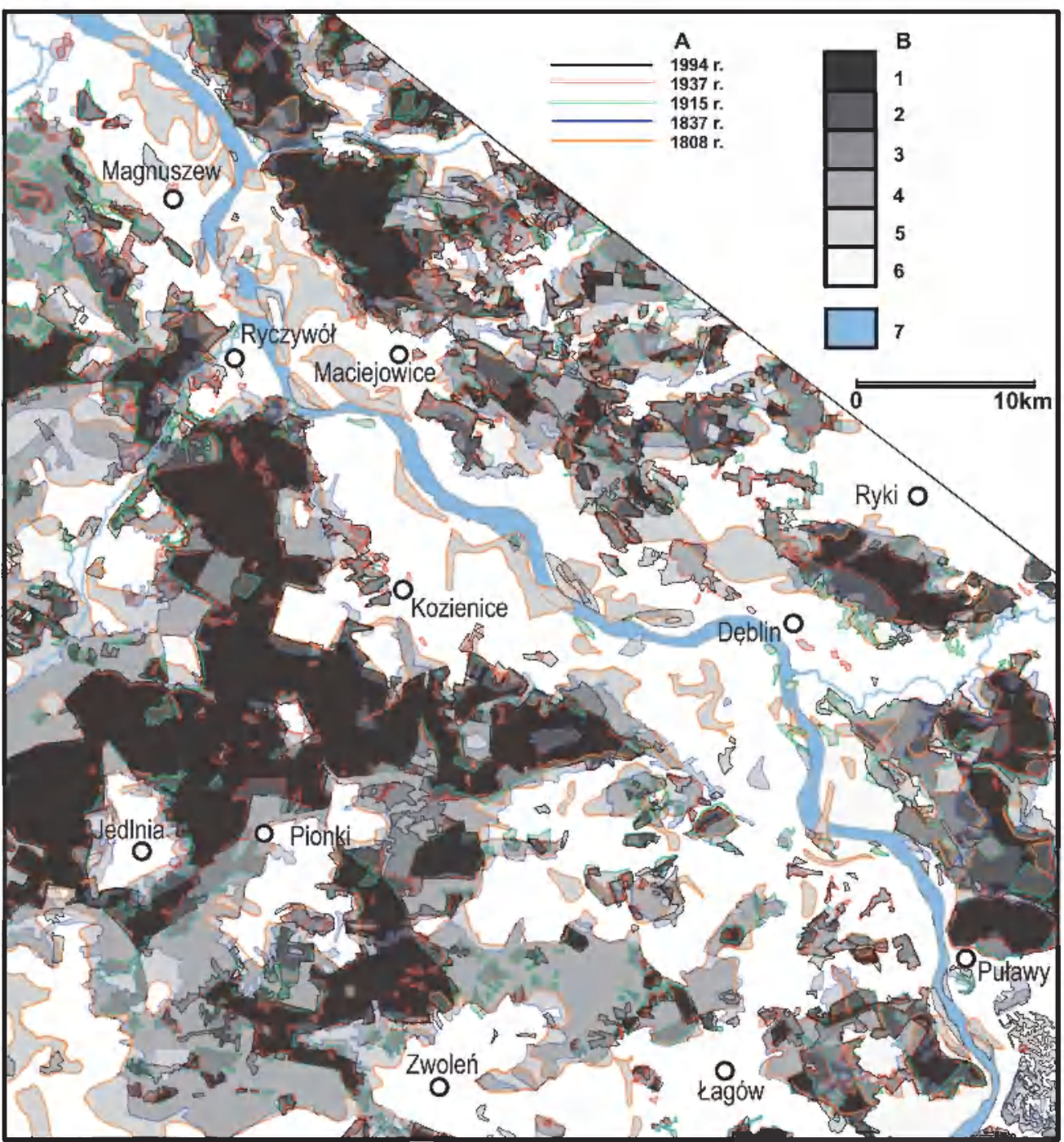

Figure 10. The permanence of forest use in southern Mazowsze in the 19th and 20th centuries

A.Limits of forest area

B. Permanence of forests

1 - areas of permanent forest utilization

2 - areas with a dominant method of forest utilization

3 - areas with a prevalent method of forest utilization

4 - areas with alternating utilization of forest

5 - areas with occasional utilization of forest

6 - non forest areas

7 -river

predominant forms of building were one-level wooden structures with gabled roofs covered in straw or shingles. Only churches, convents, palaces and the seats of royalty or the aristocracy were built of masonry. Wood being the basic building material in this re- 
Table 2. Changes in the urban network in the southern Mazowsze region ( $\mathrm{X}-25$ years)

\begin{tabular}{|c|c|c|c|c|c|c|c|}
\hline & XIV & $X V$ & XVI & XVII & XVIII & XIX & $\mathrm{XX}$ \\
\hline Sieciechów & $x x$ & $x \times x \times$ & & & & & \\
\hline Ryczywó1 & $x x$ & $x \times x \times$ & & & & & \\
\hline Magnuszew & $x$ & $x \times x \times$ & $x \times x$ & & $x \times x$ & $\times \times x$ & \\
\hline Kazimierz & $x$ & $x \times x \times$ & $x \times x \times$ & $x \times x \times$ & $x \times x \times$ & $x \times x$ & $x \times x$ \\
\hline Stężyca & & $x \times \times x$ & $x \times x \times$ & $x \times x \times$ & $x \times x \times$ & $x \times x$ & \\
\hline Łaskarzew & & $x \times x \times$ & $x \times x \times$ & $x \times x \times$ & $x \times x \times$ & $x \times x$ & $x$ \\
\hline Zwolen & & $x \times x$ & $x \times x \times$ & $x \times x \times$ & $x \times x \times$ & $x \times x$ & $x \times x$ \\
\hline Maciejowice & & & $x \times x \times$ & $x \times x \times$ & $x \times x \times$ & $x \times x$ & \\
\hline Kozienice & & & $x x$ & $x \times x \times$ & $x \times x \times$ & $x \times x \times$ & $x \times x \times$ \\
\hline Gniewoszów & & & & $x$ & $x \times x \times$ & $x \times x$ & \\
\hline Pulawy & & & & & & & $x \times x$ \\
\hline Dęblin & & & & & & & $x \times$ \\
\hline Ryki & & & & & & & $x \times$ \\
\hline Pionki & & & & & & & $x x$ \\
\hline
\end{tabular}

gion is what has ensured the survival of only scant historical buildings.

Villages in the 19th and 20th centuries most often had an arrangement of tiny streets, or were of the scattered settlement type. Presently most homes are of masonry, but the proportion of wooden buildings in the region is still great (c. 30\%). On the roofs of homes the dominant materials are sheet metal or eternite.

Characteristic for Poland are weak infrástructural development and an instability of local urban centres. In the study region it is possible to observe the degeneration of historic urban centres and the creation of other, also small-sized localities. Only Kozienice has retained its town charter throughout the entire period analysed, while Zwoleń and Łaskarzew regained theirs at given times (Table 2)

The Vistula was and is a barrier to interchange in the region; life and economic activity have been organised separately on the two sides of the river channel. From the Middle Ages onward, parallel networks of roads developed either side of the river. Earlier there were many fords and ferry crossings (which changed their locations together with the shifting of the river channel). The only period during which the Vistula did not divide, but rather unified, the region, was the 15-17th centuries, when this queen of Polish rivers became the main shipping artery as trade flourished. The number of fords over the Vistula fell drastically after the construction of flood banks in the 19 th century (today one still functions at Świerże). The first wooden bridge built in the 14th century at Stężyca operáted only quite briefly before being destroyed by flood. A railway bridge was built over the Vistula at Dęblin in the early 20 th century, and a road bridge in Pulawy between the World Wars. After World War II, a road bridge was built at Dęblin, and more recently, a second automobile bridge at Pulawy has connected the Vistula's banks.

\section{CONCLUDING REMARKS}

As the above analysis makes clear, the cultural landscape is not static - it is always in the process of becoming, subject to transformations, adapting itself to the evolution of the natural environment and societal 
change, also in the evolution of ways of using the land for production. It is not only historical events that play an important role, but also the ownership status of large land areas, as well as systems of authority.

The chronological horizon and rates of change are different for specific landscapes (e.g. for the Vistula Valley as opposed to the surrounding uplands).

By reading the cultural landscape of a region we may understand that region's specifics and thus better protect its natural, but also cultural as well as natural assets. The principles of the care and protection of cultural landscapes under conventions in international law must be considered in the determination of future land-use management.

\section{REFERENCES:}

Boesch, H. (1961), USA, opanowanie kontynentu [USA: the conquering of a continent], Wydawnictwo Naukowe PWN, Warszawa, $225 \mathrm{pp}$.

Dobrowolska, M. (1948), Dynamika krajobrazu kulturowego [Dynamics of the cultural landscape], Przegląd Geograficzny, 21, 3-4: 152203.

Dobrowolska, M. (1953), Przedmiot i metodyka geografii historycznej [The subject and methodology of historical geography], Przeglad Geograficzny, 25, 1:57-71.

Ducan, J.,S. (1990), The city as text: The politics of landscape interpretation in the Kandyan kingdom, Cambridge University Press. Cambridge.

Kondracki, J. (1977), Regiony fizycznogeograficzne Polski [Physico-geographical regions of Poland], Wydawnictwo Naukowe PWN, Warszawa.

Kostrowicki, A.S. (2007), Kierunki Świata zywego Polski pod wplywem oddzialywań czlowieka [Directions of anthropogenic transformations of Poland's animate world] in: Znaczenie badań krajobrazowych dla zrównoważonego rozwoju [The role of landscape studies for sustainable development], Uniwersytet Warszawski, Wydział Geografii i Studiów Regionalnych. Warszawa, 196-202.
Kucera, Z., Kucerova-Kuldova, S., Chromy, P. (2008), Landscape heritage between areal preservation and areal development-The case of Czechia, Geographia Polonica, 81, 2: 5-24.

Kurzyp, K. (1989), Stężyca nad Wista [Stężyca on the Vistula River], Towarzystwo Przyjaciól Stężycy.

Matuszkiewicz, W. (ed). (1995), Potencjalna Roślinność Naturalna Polski. Mapa przegladowa 1:300 000. Arkusze 1-12, [Potential natural vegetation of Poland. Survey map 1: 300 000. Sheets 1-12]. IGiPZ PAN, Warszawa.

Myga-Piątek, U. (2001), Spór o pojęcie krajobrazu w geografii i dziedzinach pokrewnych [Controversy over the landscape idea in geography and related branches], Przeglad Geograficzny, 73, 1-2: 163-176.

Myga-Piątek, U. (2005), Krajobraz kulturowy w badaniach geograficznych [Cultural landscapes in geographical research], in: Krajobraz kulturowy. Aspekty teoretyczne i metodologiczne, Prace Komisji Krajobrazu Kulturowego PTG, 4: 40-53.

Numeryczna Mapa Polski [Numerical Map of Poland] 1:200 000, Instytut Geografii i Przestrzennego Zagospodarowania (IGiPZ) PAN.

Pałucki, W. (ed.) (1993), Atlas Historyczny Polski. Województwo Sandomierskie $w$ drugiej potowie XVI w. [Historical Atlas of Poland. Sandomierz Voivodeship in the second half of the $16^{\text {th }}$ century]. Wydawnictwo Naukowe PWN, Warszawa, $176 \mathrm{pp}$.

Pałucki, W. (ed.) (1973), Atlas Historyczny Polski. Mazowsze w drugiej potowie XVI w. [Historical Atlas of Poland. Mazovia in the second half of the $16^{\text {th }}$ century]. Wydawnictwo Naukowe PWN, Warszawa, $255 \mathrm{pp}$.

Plit, J. (2003), Czynniki degradacji lasów i ich skutki dawniej i dziś (na przykladzie Puszczy Kozienickiej) [Factors in forests decline and its ancient and modern results (as exemplified by Kozienicka Forest], in Śmigielska, M., Slodczyk, J. (eds.) Geograficzne aspekty globalizacji i integracji europejskiej [Geographical aspects of globalization and European integration], Opole, 125-132.

Plit, J. (2004), Changes in the settlement system and land use in the valley of the Vistula river in historical times (on the segment between War- 
gocin and Magnuszew), in Dobrzańska, H., Jerem, E., Kalicki, T. (eds.), The geoarcheology of river valleys, Budapest, 143-159.

Plit, J. (2004), Changes in the middle course of the River Vistula in historical time, $\mathrm{Ge}$ ographia Polonica, 77, 2: 47-61.

Sauer, C. (1925), The Morphology of landscape, University of California Publications in Geography, 2: 19-53.

Solon, J. (2008), Typy krajobrazu kulturowego Polski [Types of cultural landscape of Poland], in: Klasyfikacja Krajobrazu Teoria i Praktyka [Landscape classification. Theory and practice], Problemy Ekologii Krajobrazu, vol. 20: 109-115.

Wąsowiczówna, T. (1957), Wczesnośredniowieczne przeprawy przez środkowa Wiste [Early medieval crossings of the middle course of the River Vistula], Kwartalnik Historii Kultury Material$n e j, 5$ (3): 433-453.

Wojciehowski, S. (ed.) (1966), Atlas Historyczny Polski. Województwo lubelskiego $w$ drugiej polowie XVI wieku [Historical Atlas of Po- land. The Lublin Voivodeship in the second half of the $16^{\text {th }}$ century] Wydawnictwa Naukowe PWN, Warszawa, 46 pp.

Zaręba, R. (1963), Puszcza Kozienicka w XVIII wiek $u$ [The Kozienice primaeval forest in the 18th century], Kwartalnik Historii Kultury Materialnej, 11 (2): 258-269.

Zaręba, R. (1974), Zmiany w drzewostanie $i o b-$ szarze Puszczy Kozienickiej i Stromeckiej wywotane procesami gospodarczymi [Changes in the stand and area of the Kozienicka and Stromecka primaeval forests induced by economic processes], Biuletyn Kwartalny Radomskiego Towarzystwa Naukowego, 11 (3-4): 157-167.

Zielony, R. (ed.) (1997), Lasy Puszczy Kozienickiej, monografia przyrodniczoleśna [The Kozienicka forest, a nature monograph], Wydawnictwa SGGW, Warszawa, 324 pp.

Paper first received: May 2010

In final form: September 2010 
http://rcin.org.pl 


\section{INFORMATION FOR AUTHORS}

The editors of Geographia Polonica invite theoretical and empirical contributions to human as well as physical geography, in broad terms. Articles are expected to be original and not yet published elsewhere unless in languages other than English.

MANUSCRIPTS. Manuscripts, in the English language, should be submitted to the Editor of Geographia Polonica (Institute of Geography and Spatial Organization, Polish Academy of Sciences, Twarda 51/55, 00-818 Warszawa, Poland; E-mail: geographia.polonica@twarda.pan.pl).

As all manuscripts will be reviewed, therefore, authors are kindly requested to provide a hard copy of the complete text (main text, abstract, references, tables, illustrations) and an electronic version of the manuscript in MS Word. Also, please include phone, fax and email addresses.

The manuscripts should be arranged in the following order. First sheet: title, full name of author(s), affiliation, full postal adress, e-mail address. Second sheet: abstract of no more than 100 words, key words (3-10) at the end of the abstract. Subsequent sheets: the main text of about 20-25 pages (in A4 format). Then on separate sheets: acknowledgement (if desired), notes, references, tables, illustrations, captions to illustrations.

The main text may be organized in sections under appropriate headings without numerals. Manuscripts should be printed with 1,5 lines spacing without indents; for paragraphs enter a line space.

REFERENCES should be printed in alphabetical sequence at the end of the text. Examples:

Articles from journals:

Perroux, F. (1950), Economic space: Theory and applications, Quarterly Joumal of Economics, 64: 89-104.

Kotarba, A. (1992), Denudacja mechaniczna Tatr Wysokich pod wpływem opadów ulewnych [Mechanic denudation in the High Tatra Mountains caused by downpours], Prace Geograficzne 195, Instytut Geografii i Przestrzennego Zagospodarowania (IGiPZ), PAN: 191-208.

Books:

Stren, R.,White, R. and Whitney, J. (1992), Sustainable cities, London, Jessica Kingsley Publishers.

Chapters from books:

Dematteis G., (1996), Toward a unified metropolitan system in Europe: Core centrality versus network distributed

centrality, in Pumain, D. and Saint-Julien, T. (eds.), Urban networks in Europe, INED, John Libbey, Paris, 19-28. Theses:

Elfring T., (1987), Service employment in advanced economies, Unpublished Ph.D. thesis, Rotterdam, Erasmus University, School of Management.

References should be indicated in the text by listing, in parenthesis, the author's name followed by the data of publication, e.g. (Kowalski 1995) or (Kowalski and Brown 1996) or (Kowalski et al. 1997) if there are more than two authors (Note: all the authors should be listed in the references).

FOOTNOTES and NOTES should be referred to by superscript letters.

ILLUSTRATIONS should be supplied in one of the following formats:

- photographs: JPG, TIFF, EPS or PSD,

- maps, figures and diagrams should be presented as vector files in $\mathrm{AI}$ (Adobe Illustrator) or one of the format mentioned above.

Please ensure that the resolution is not lower than $300 \mathrm{dpi}$ and the lines are a minimum of 0.3 points thick. Please also supply printouts of illustrations that are to be presented, in black and white or in colours, in relation to the required final appearance in print.

TABLES should be printed on separate sheets and numbered sequentially with Arabic numerals (e.g. Table 1). Each table should be provided with a clear descriptive caption at the top and informative column headings.

EQUATIONS and symbols used in mathematical formulae must be clearly explained. Axes on graphs should be described clearly. Units and abbreviations used by authors should conform to the International List.

MEASUREMENTS should be given in metric units.

ACCEPTED MANUSCRIPTS. After acceptance for publication, authors will receive page proofs for approval before publication. The revised manuscript should be returned promptly to the Editor.

Articles accepted for publication in Geographia Polonica are not honoured financially. Authors of accepted articles will receive one copy of the journal free of charge.

Authors are responsible for indicating copyright as well as permission from the copyright holder to reproduce any texts, tables or illustrations for which copyright exists. 
Vol. $84 \quad$ No. 1

\section{CONTENTS}

\section{ARTICLES}

STANISŁAW KĘDZIA

The influence of relief on microclimate and location of the upper tree-limit

\section{JÓZEF ŻYCHOWSKI}

The impact of cemeteries in Kraków on the natural environment - selected aspects

WŁADYSŁAW NIEWIAROWSKI, RAFAŁ KOT

Delimitation and characteristics of natural landscapes of the Chełmno-Dobrzyń Lakeland, Urszulewo Plain and the neighbouring Vistula and Drwęca Valleys

\section{MAREK DEGÓRSKI}

The relationships between different forms of iron and aluminium in soils as indicators of soil-cover development on India's Cherrapunji Spur (Meghalaya Plateau)

\section{EWA LUBERA}

Tors of the Chocholowska Valley (Western Tatra Mountains)

JOANNA PLIT

Evolution of the South-Mazovian cultural landscape 